\title{
The Enforceability Force Majeure's Clause In Performance Of Business Contracts During Pandemic Covid-19 In Indonesia
}

\author{
Nizam Zakka Arrizal ${ }^{1}$ \\ ${ }^{1}$ University of PGRI Madiun, Madiun - Indonesia \\ E-mail : chagnizam@gmail.com
}

\begin{abstract}
This study examines the enforceability of Force Majeure's clauses in the Performance of business contracts during the covid-19 pandemic in Indonesia, so that a study of the problem with the legal issues discussed are Is the Covid-19 Pandemic a force majeure? and What is legal consequences as a result of the force majeure agreement in implementing contracts during the Covid 19 pandemic? The method used is a normative juridical research method, namely research on legal principles using secondary data. While the data analysis method used is a qualitative method and the data collection tool used is the study of documents. The results of this study are The Covid-19 pandemic can be categorized as force majeure as long as it is proven by the debtor by paying attention to three instruments such as the Agreement, Article 1244 jo. $1245 \mathrm{BW}$, and Government Policy. If the debtor cannot prove this, the debtor is declared to have broken his promise to the creditor. If the debtor can prove it and the creditor agrees, there are several legal steps that can be taken, namely: delaying the implementation of the agreement by making an addendum or canceling the agreement.
\end{abstract}

Keywords- Force Majeure; Business Contracts; Pandemic Covid-19

\section{INTRODUCTION}

At first, Covid-19 only spread to three Indonesians. However, after a period of time, there were many people with an increase of about a thousand each day. Of course this is a concern and a danger to at least three aspects of life that have the most impact, namely health, economy and education. The economic sector, as the support for the other two fields, must continue to exist in order to ensure that the other two fields can survive. In this economic sector, one of its activities is business.

Law is the frame in every business activity.[1] Humanity cannot be separated from business activities because human nature is an economic being as well as a social being. In every trade and transaction, humans must actually carry out legal actions that are proven from business construction such as buying and selling, leasing, grants, and many more. All these constructions are legal acts and are regulated by civil law.

Almost all business activities or business sectors have been affected by the Covid-19 pandemic. Among them: transportation, hotels, tourism, malls, entertainment, umkm, restaurants, cafes, banking, and so on. There are also sectors that are affected but not as much as the previous sectors, including pharmaceuticals, medical devices, telecommunications, and shops for basic necessities.

The impact on the above sectors is the decline in company income due to lack of consumers. The decrease in income will affect the company's finances for spending or production processes. So that business partners who will later be affected too.

The government issued several regulations that directly or indirectly hinder and hinder business people from running their business, including largescale social restrictions with the main objective of issuing them for the sake of citizens, namely the principle of salus populi suprema lex esto, which means that people's safety is the highest law. Health is the government's top priority in preventing the spread of covid-19.

In business law, agreements as an instrument of guardianship of legal relations play an important role. When the movement of business actors is limited, the law must continue to play a role and be at the forefront of guaranteeing human rights. During the Covid-19 pandemic, of course many business actors were hampered from doing their activities and running their businesses due to the obstacles mentioned above. This situation is prone to conflict because Covid-19 comes accidentally and suddenly so there needs to be a study on force majeure.

The government's hope turns out to have a negative side, namely reduced social or face-to-face interaction, decreased economic growth, sluggish 
business transactions, reduced tax revenue, this is because Covid-19 is very easily transmitted between humans and no cure has been found. Only immunity can treat positive patients from this outbreak.

Force majeure is indeed a threat to the sustainability of the implementation of business contracts because it does not come from parties but from outside and is caused by natural disasters. Therefore, the arrangement in the contract must be comprehensive. In business contracts, there are various mentions of force majeure, including force majeure, overmacht, act of God, force, and vis major. In French, it is known as superior force, which means an event that cannot be controlled by humans.

Force majeure is a foreign term because it doesn't come from Indonesia. Nonetheless, the force majeure clause is fundamental in the preparation of business contracts because as a preventive and repressive instrument, accidents or extraordinary events occur that hinder the execution of contracts to the parties.

The agreement made legally binds the parties such as the law as per the principle of the pacta sunt servanda regulated in Article 1338 of the Civil Code (called BW). The validity of this agreement is of course based on Article 1320 BW, which one of the elements is agree. People who agree, of course, have this awareness that must underlie the continuity of the agreement, starting from before making the agreement to implementing the agreement.

Humans are equipped with various characters and traits, one of which is laziness, naughty, and broken promises. The state of covid-19 is an opportunity for fraudulent business people to deliberately deviate from contracts by not fulfilling contractual obligations under the pretext of covid19.

\section{PROBLEMS}

The legal issues of this research are:

1. Is the Covid-19 Pandemic a force majeure?

2. What is legal consequences as a result of the force majeure agreement in implementing contracts during the Covid 19 pandemic?

\section{RESEARCH METHOD}

Form of this research is juridical normative, namely by examining written legal norms directly on the subject matter which is the subject of this research.[2] The data used in this study, namely secondary data that is not obtained directly from the field but through the process of searching for library materials, and in the form of secondary legal material in the form of theories taken from various literature works, the 1945 Constitution of the Republic of Indonesia and laws and regulations.

Researchers used data collection tools in the form of document studies and theories and existing regulations. The data analysis method used in processing the data related to this research is a qualitative method because data processing is not done by measuring the secondary data related to it, but descriptively analyzing the data. In a qualitative approach, research procedures produce descriptive analytical data.

\section{DISCUSSION}

World was shocked by the emergence of a virus at the end of 2019 called Covid-19 (corona virus disease 2019). This virus originated from the city of Wuhan in Tiongkok and then spread to all countries in the world and became an outbreak of a disease with very fast transmission. WHO declared Covid19 as global pandemic on March $11^{\text {th }} 2020$. This condition causes international life not run as it should be, business life is no exception.

The government has issued several policies to respond to the covid outbreak and the policies made before related to health by issuing the following regulations:

a) Law Number 4 year 1984 concerning Infectious Disease Outbreaks;

b) Law Number 24 year 2007 concerning Disaster Management;

c) Law Number 36 Year 2009 regarding Health;

d) Government Regulation in Lieu of Law Number 1 of 2020 concerning State Financial Policy and Financial System Stability for Handling the 2019 Corona Virus Disease (COVID-19) Pandemic and / or in the context of Facing Threats that Endanger the National Economy and / or Financial System Stability;

e) Government Regulation Number 40 of 1991 concerning prevention of infectious disease outbreaks;

f) Government Regulation Number 21 of 2020 concerning Large-Scale Social Restrictions in the Context of Accelerating the Handling of Corona Virus Disease 2019 (COVID-19); 
g) Presidential Regulation Number 17 of 2018 concerning the Implementation of Disaster Emergencies Under Certain Conditions;

h) Presidential Decree No.11 of 2020 concerning the Determination of the 2019 Corona Virus Disease (COVID-19) Public Health Emergency;

i) Presidential Decree Number 12 of 2020 concerning the Designation of Non-Natural Disaster for the Spread of Corona Virus Disease 2019 (COVID-19) as a National Disaster;

j) Presidential Instruction Number 4 of 2019 regarding Capacity Building To Prevent, Detect And Respond To Disease Outbreaks, Global Pandemics, And Nuclear, Biological And Chemical Emergencies;

k) Regulation of the Minister of Health Number 9 of 2020 concerning Guidelines for LargeScale Social Restrictions in the Context of Accelerating the Handling of Corona Virus Disease 2019 (COVID-19);

1) Decree of the Minister of Health of the Republic of Indonesia Number HK.01.07 / MENKES / 239/2020 concerning Stipulation of Large-Scale Social Restrictions in the DKI Jakarta Province in the Context of Accelerating the Handling of Corona Virus Disease 2019 (COVID-19);

m) Decree of the Minister of Health of the Republic of Indonesia Number HK.01.07 / MENKES / 248/2020 concerning Stipulation of Large-Scale Social Restrictions in the Bogor Regency, Bogor City, Depok City, Bekasi Regency and Bekasi City, West Java Province in the Context of Accelerating the Handling of Corona Virus Disease 2019 (COVID-19);

n) Decree of the Head of the National Disaster Management Agency Number 13.A. Year 2020 concerning the Extension of the Status of Certain Disaster Emergency Disaster Outbreaks of Corona Virus in Indonesia;

o) Provincial and Regency / City Regional Regulations concerning the Implementation of Large-Scale Social Restrictions, for example the Regulation of the Governor of the Special Capital Region of Jakarta Number 33 of 2020 concerning Implementation of Large-Scale Social Restrictions in Handling Corona Virus
Disease 2019 (Covid-19) in the Special Capital Region of Jakarta Province;

The regulations above have the scope of health and handling of the prevention of Covid-19. All of them do not discuss force majeure specifically and do not categorize covid-19 as force majeure. However, it is a reference for providing legal analysis in this research..

Juridically, Force majeure is regulated in the Indonesia Civil Code (herein after called BW) which is the basic positive law in the discipline of civil law. In addition, force majeure is also regulated in an agreement or contract as the legal basis for conducting the parties' business. Force majeure in BW regulated in several Articles, the most important of them are based on Articles 1244 and 1245 BW. Even though these two articles do not mention the term force majeure implicitly, experts use it as the basic norm of force majeure in contract law.

Article 1244 of the Civil Code:

"If there is a reason for that, the debtor must be punished to compensate costs, losses and interest if he is unable to prove that the agreement was not carried out or not at the right time, due to an unforeseen thing. cannot be held accountable to him, all of that even if bad faith is not on his side. "

From Article 1244 BW above, force majeure has several elements that are cumulative. This means that all elements must be fulfilled if a situation is declared as force majeure or one element is not fulfilled, then the condition is not force majeure. The elements of Article $1244 \mathrm{BW}$ are as follows:

1. There are condition that are unexpected;

2. Obligation that have not or cannot be implemented;

3. Not the debtor's fault;

4. There is no bad faith.

Article 1244 BW contains elements of force majeure. Meanwhile, due to force majeure is regulated in the next article, namely article 1245 BW. The content of Article $1245 \mathrm{BW}$ is as follows:

"It is not the cost of loss and interest, it must be replaced, if due to coercive circumstances or because of an accidental incident the debtor is unable to provide or do something required, or because the same things have committed a prohibited act."

Article 1245 BW regulates that debtors who are unable to carry out their obligations due to force majeure are not required to pay compensation and 
interest. The existence of the norm of article 1245 $\mathrm{BW}$ is intended so that with the occurrence of force majeure, the debtor immediately cannot be declared in default (in Indonesia Wanprestasi) because the implementation of his performance is hindered due to an incident other than the debtor's fault so that the debtor does not pay compensation and interest like it should be done.

Failure to fulfill obligations due to in default by the debtor is not valid if the debtor can prove that the failure was not caused by the debtor himself. In this case, the default clause in the agreement or in BW cannot be enforced as long as the debtor proves concretely the existence of force majeure.

Articles 1244 and 1245 BW are the most basic legal basis regarding force majeure. In addition, there are several articles in BW that regulate force majeure which are located scattered in the third book of BW. Article $1545 \mathrm{BW}$ regarding the exchange (rulling) stipulates that if a certain item which has been promised to be exchanged is destroyed (musnah) outside of the wrong of owner then the agreement is categorized null and void and who from his party has fulfilled the agreement can claim back the goods he has given in exchange.

These articles are regulated in the third book BW. The third book of the Civil Code is regelend (regulating), meaning that the articles in the third book of the Civil Code are open to parties and seem not as rigid as the second book of the Dualend Civil Code. This also applies to the provisions of force majeure which are contained in the third book of the Civil Code. This means that the force majeure provisions in Articles 1244 and 1245 BW are open and not narrow so that the parties can specifically regulate the contract.

To be able to say a "coercive condition," (overmacht or force majeur), apart from that, "beyond his control" the debtor and "coercive," the condition which has arisen must also be a condition which cannot be known at the time of the agreement. is made, at least not risked by the debtor. If the debtor succeeds in proving the existence of such a situation, the debtor's demands will be rejected by the judge and the debtor will escape the punishment, either in the form of punishment for fulfilling the agreement, or punishment to pay compensation.[3]

The burden of proof lies with the debtor. Debtors who have the obligation to carry out achievements must prove that their inability does not come from the debtor, Covid-19 actually hinders and hinders the implementation of debtors' obligations, the debtor is not guilty of the emergence of Covid-19, the Covid-19 pandemic was not taken into account and was not suspected by the debtor.

According to Blacks law dictionary, force majeure occurs when business is disrupted due to a factor beyond control. [4] Force majeure is an event or effect that cannot be reasonably anticipated or controlled. [5]

There are two types of force majeure, namely absolute majeure and relative force majeure.

1. Absolute Force Majeure

is a condition in which the debtor cannot carry out his obligations or achievements at all because the object of the agreement has been destroyed. This type is a natural disaster that causes the object of the agreement to be destroyed so that the debtor cannot carry out his obligations. For example, because of an earthquake, houses that were used as objects for buying and selling were completely destroyed. The material and its contents are still there, but the shape is no longer a house to live in, but only ruins that cannot be enjoyed by the buyer.

Absolute force majeure or also called absolute force majeure in the case that it is no longer possible to carry out the agreement (for example, the goods have been written off due to natural disasters). If the goods have been destroyed apart from the fault of the debtor, then of course the implementation of the agreement cannot be sued by the creditor. The problem is if goods are destroyed but there are substitutes, this of course must include the judge who will weigh and evaluate them later. If indeed the situation is force majeure, then this condition must be totally impossible for achievement and achievement compensation to be held.

\section{Relative Force Majeure}

is a situation where the debtor is still possible to perform his performance. This type of force majeure relates to the debtor's condition that makes it impossible to carry out his obligations. For example, fishermen who enter into credit agreements promise to pay for their performance after selling their catch, but cannot immediately do so because the weather and sea waves force fishermen not to go to sea. However, it is still possible to pay the credit after the fishermen go back to sea.

Force majeure is relatively in the form of a condition in which the agreement can still be carried 
out, but with enormous sacrifices from the right of the debtor. For example, the price of goods that the seller still had to bring in suddenly soared very high or suddenly the Government issued a regulation prohibiting the issuance of certain goods from an area, which caused the debtor to be unable to send the goods to the debtor.

Abdulkadir Muhammad tried to detail the absolute nature and not (relative) of overmacht as follows:[6]

a. A situation that shows that the achievement cannot be fulfilled because of an event that destroys (destroys) and destroys the object of the agreement. This situation shows the absolute nature of force majeure.

b. A situation that indicates that the achievement cannot be fulfilled because of an event that can prevent the debtor's actions from fulfilling the achievement. This state can be absolute or relative.

c. A situation that shows uncertainty because it cannot be known or expected to occur when entering into an agreement by both the debtor and creditor. This situation shows that the fault is not on both parties, especially the debtor.

The condition forcing according to classical legal scholars is interpreted as a condition that is absolutely unavoidable by the debtor to perform performance against an obligation. Their minds are drawn to natural disasters or accidents that are beyond human ability to avoid, making it impossible for the debtor to keep his promises. For example, the promised object has been destroyed. This view has begun to recede with the argument that the overmacht can be relative, provided that the obligations imposed on debtors can be carried out through other means.[7]

In business law, there is one adage that is, whoever is guilty is obliged to bear the risk. [8] This is indicated by Article $1236 \mathrm{BW}$ as the basis for categorizing people as defaulting. This article is to emphasize who has to bear the risk. In addition, there are also several articles including articles $1239,1241,1242$, and $1243 \mathrm{BW}$ as a line of articles to demand compensation for the opposing party.

The above conditions are caused because the debtor deliberately and understands that his actions have violated the agreement. Meanwhile, if the default arises due to accidental debtor due to circumstances beyond his fault, namely force majeure. BW does not regulate force majeure comprehensively, BW does not regulate specifically and is regulated separately.

Force majeure is set separately in BW. This aims to patch or cover the general rules that are less specific in Articles 1244 and 1245 BW. If the goods which are the object of exchange are destroyed, the agreement is considered null and void as mandated by Article $1545 \mathrm{BW}$. In the case of leasing this is also the case, as Article $1553 \mathrm{BW}$ states, if the object is destroyed due to the fault of the parties, then the agreement is considered null and void. There are no claims for compensation and are allowed to demand reduced rent or cancellation of the agreement.

Force majeure is a debtor's step to avoid claims for compensation. Apart from force majeure, there are other efforts, namely rechtsverwerking and exceptio non-compliance contractus. A force majeure event must be an event that cannot be predicted beforehand. If an event has been calculated and suspected then it is not force majeure. For example, at the beginning of the year the south coast must have big waves, but the seller still promises to supply fish to the buyer's company even though he will find it difficult to find fish at that time. He is aware and it is generally known that this condition is not force majeure but default.

Debtors who argue that force majeure must continue to carry out their obligations because their obligations are not destroyed like their property. He must bear the risk and prove the force majeure, namely: there has been an event that hinders the fulfillment of the achievement, the event was never predictable beforehand, and the incident arose out of the debtor's error. Again, force majeure is an excuse to avoid claims for compensation (not to avoid contractual obligations). If force majeure is clearly proven, then he is free from compensation.

In commercial business practice, examples of force majeure are of many types including: natural disasters (earthquakes, landslides, floods, or fires), wars, terrorism, riots, government policies, and others. In these circumstances, the debtor can be blamed and exempted from fulfilling his obligations. However, as long as he does not have bad faith and he proves that this situation has fulfilled the force majeure element as in the agreement.

Talking about force majeure cannot be separated from articles $1444 \mathrm{BW}$ and $1445 \mathrm{BW}$. These two 
articles stipulate that if the object of the agreement is completely destroyed, the result will be a nullification agreement, which means that the agreement is deemed to have never existed and the legal state is returned to its original state.

Force majeure is a concept in civil law and is accepted as a principle in law. Mochtar Kusumaatmadja stated that force majeure or vis major can be accepted as an excuse for not fulfilling the implementation of obligations due to the loss / disappearance of the object or objective that is the subject of the agreement. This situation is aimed at physical and legal implementation, not only because of difficulties in carrying out obligations. Mieke Komar Kantaatmadja shared a similar view, namely: [9]

a. A change in circumstances does not exist at the time of the formation of the agreement;

b. The change concerns a condition which is fundamental to the agreement;

c. These changes cannot be predicted in advance by the parties;

d. The result of these changes must be radical, thus changing the scope of the obligations that must be carried out according to the agreement;

e. The use of this principle cannot be applied to border agreements and also changes in circumstances due to violations committed by the party filing the demands;

Rahmat SS Soemadipradja explained that when compared with the scope of force majeure regulated in the Civil Code, there are developments that occur, that the scope of force majeure is no longer limited to natural events or the act of God, and the loss of the promised object, but it has extended to administrative actions of the ruler, political conditions such as war. These developments are as follows: [10]

a. The risk of war, loss of the object of the agreement caused by the power of the Most High: struck by lightning, fire, confiscated by the Japanese army during the war (Supreme Court Decision No. Reg. 15 K / Sip / 1957);

b. Act of God, administrative actions of the authorities, orders from those in power, decisions, all administrative actions that determine or bind, a sudden event that cannot be resolved by the parties to the agreement
(Supreme Court Decision No. 3389 K / Pdt / 1984);

c. Government regulations (Supreme Court Decision No. Reg. 24 K / Sip / 1958); Both PN and PT stated that what was stated by the defendant Super Radio Company NV could not be used as an excuse for force majeure because if the defendant could not get an AJS motorbike from NV Danau due to the issuance of government regulations (KPUI) on the prohibition of importing more than one brand motorbike, in order to fulfill his obligations to the plaintiff, he must try / try to get the motorcycle from NV Ratadjasa or by other means, as long as it does not violate the law. Both PN and PT stated that the defendant Super Radio Company NV had neglected their obligations.

d. Accidents at sea, for example a ship sinking because big waves hit the hull of the ship (Supreme Court Decision No. 409 K / Sip / 1983);

e. State of emergency (Supreme Court Decision No. Reg. 1180 K / Sip / 1971);

f. Completely unpredictable and / or very compelling situations or circumstances that occur outside the control of the party that must perform (Decision No. 21 / Pailit / 2004 / PN.Niaga.Jkt.Pst)

The parties must carry out the contract in good faith whatever the circumstances that occur during the implementation of the contract as mandated by Article 1338 of the Civil Code. In fact, the principle of good faith is not only at the time of contract execution, but also when making contracts must be based on good faith. This is of course important because when the contract is drawn up, the parties will make articles that will be binding when its implementation.

The parties' legal steps in dealing with the Covid19 pandemic are to agree that the Covid-19 pandemic is force majeure. The agreement can be done by making an addendum to the agreement. This addendum can be in the form of an agreement amendment, an agreement addendum, or an additional agreement which is an integral and inseparable part of the main agreement. One of the articles in the addendum essentially changes the force majeure provisions in the contract by adding 
the Covid-19 pandemic disaster to a force majeure state.

If the parties have not regulated force majeure in the agreement, the parties can add a force majeure article to the addendum. The making of this addendum, of course, begins with negotiations between the parties first. The party that is burdened with the obligation to carry out performance proposes to the creditor so that the performance can be postponed or canceled.

The postponement of implementing achievements starts from the start of the pandemic until the pandemic is over. The delay does not remove or eliminate the debtor's obligation to perform achievements. Debtors are required to carry out achievements when the pandemic has ended.

The cancellation of the implementation of the achievement was agreed upon because it was not known when the covid-19 pandemic would end. If an achievement is forced on the contract, it will actually burden the implementation of other achievements or cause uncertainty regarding the implementation of the entire agreement. Regarding the cancellation of the implementation of this achievement, it is usually replaced by other relevant achievements.

The application or categorization of the Covid19 pandemic into a force majeure clause cannot be arbitrary. Categorization cannot be based on laws and regulations relating to the Covid-19 pandemic, press releases of the task force handling Covid-19, or mass media coverage. Categorization must be based on case by case (case by case)

Aside from being based on agreement, the application of force majeure must be based on comprehensive and real analysis and calculations. The analysis is based on the state of the company affected by Covid-19. What needs to be considered is that a case that applies Covid-19 as a force majeure is different from the cases experienced by other companies. So that proving covid-19 as a force majeure must be done independently and internally.

Even so, it is also possible if one of the parties objected to categorizing the Covid-19 pandemic into force majeure. If so, the contract must be carried out properly as if there was no Covid-19. If the parties agree to categorize the Covid-19 pandemic as force majeure, there are several legal consequences.

There are several reasons that can be used as the basis for determining that Covid-19 is force majeure. Among them: there are obstacles for debtors to implement the agreement due to government policies in the form of social restrictions to prevent the spread of covid, debtors do not know if there will be covid and when it will end, covid occurs not at the will of the debtor.

Juridically, covid-19 cannot be categorized as force majeure because the author believes in the agreement made before the covid-19 pandemic did not explicitly state that covid-19 was a force majeure. Moreover, all of the above regulations also do not mention that Covid-19 is a force majeure in business contracts. That is why parties, especially debtors who have obligations / achievements, must prove that the conditions at the time of Covid-19 were a force majeure.

There are several reasons showing that covid-19 is force majeure. Among them, with the issuance of Presidential Decree 11/2020 and its implementing regulations, the community carried out activities instructed by the government, namely large-scale social restrictions, physical distancing or social distancing, temporary closure of business activities, reduction of working hours, prohibition of largescale gatherings and so on. These activities hinder business actors from running their business (running business).

Particularly for agreements related to credit / public finance, there is a dispensation with direct policy from the government. This is based on the Permenkeu. So the debtor is free to pay installments / installments until February 2021. The time to postulate Covid-19 as force majeure can be done at any time during the implementation of the agreement. According to Subekti [7], a debtor can postulate force majeure when he is being sued in court. A debtor who is sued before a judge because he is said to have neglected his obligations can defend himself to prevent himself from detrimental punishment by bringing up conditions beyond his control that compel him to fail to keep the agreement (overmacht). The defense was intended so that he would not be blamed for not keeping the agreement.

In practice, some of the state regulations above have hindered and hindered business actors from running their business. If the debtor forces his will to continue to fulfill his obligations, he will be subject to sanctions. For example, the debtor was in Jakarta, which at that time had a PSBB policy and the closure of offices and places of business to 
prevent the spread of Covid-19. If he continues to open a business and runs the business to fulfill contractual obligations, he may be punished by the provincial government. What's worse, he can contract the Covid-19 disease.

The last instrument for determining force majeure conditions is the judge. Parties who cannot equate their perceptions regarding whether the Covid-19 outbreak is a force majeure or not can ask the judge to resolve the dispute by filing a lawsuit in court. At the trial, the judge will assess the arguments of both parties.

If the debtor cannot prove the state of the Covid19 pandemic as a force majeure, then failure to fulfill the debtor's obligations can be categorized as negligent debtors. Creditors can demand several things from the negligent debtor. [7] The creditor can choose between various possibilities.

1. First, he can ask for implementation of the agreement even though implementation is too late.

2.Second, he can only ask for compensation, namely the losses he suffered because the agreement was not carried out or was late or implemented but not as it should have been.

3. Third, he can demand that the implementation of the agreement be accompanied by compensation for losses suffered by him as a result of the delay in implementing the agreement.

4. Fourth, in the case of an agreement that places reciprocal obligations, the negligence of one party gives the other party the right to ask the judge to cancel the agreement accompanied by a request for compensation.

Parties who agree to include covid as force majeure must also know that the agreement has not been canceled and is still valid. It's just that the implementation is delayed or the object is replaced with other items. This is a form of legal certainty for the implementation of the contract and is the principle for the elimination of the engagement as referred to in Article $1381 \mathrm{BW}$.

As a result of force majeure, according to Asser in the book Study of the Dutch Civil Law (pp. 368 369) there are two possibilities, namely termination of the agreement or suspension of obligations. [11] Termination of the agreement occurs when the obstacle is permanent. For example, a singer who has signed a contract to appear at a concert suddenly has his throat operated on, so that it is no longer possible for him to sing again. In this situation the force majeure caused the termination of the agreement.

With the end of the agreement, the contra performance also ends, for example the obligation of the concert organizer to pay the singer. The suspension of liability occurs when a force majeure event is temporary. When the condition of the obstacle has recovered, for example the export ban is lifted again, then the obligation of the seller will recover to hand over the exported goods.

The implementation of the agreement is very dependent on the content contained in the agreement. So that the material of the agreement must be made perfectly when drafting the agreement or making the contract, in this case when the contract drafting. Each article in the agreement will have legal consequences for the parties.

\section{CONCLUSION}

The Covid-19 pandemic can be categorized as force majeure as long as it is proven by the debtor by paying attention to three instruments such as the Agreement, Article 1244 jo. 1245 BW, and Government Policy. If the debtor cannot prove this, the debtor is declared to have broken his promise to the creditor. If the debtor can prove it and the creditor agrees, there are several legal steps that can be taken, namely: delaying the implementation of the agreement by making an addendum or canceling the agreement.

\section{ACKNOWLEDGEMENT}

I say thank to Allah, my family, Universitas PGRI Madiun, and all friends who support me to finish this research.

\section{REFERENCES}

[1] Isnaeni, Moch. Implementation of contractual obligations and application of force majeure clauses in agreements in the midst of the Covid-19 pandemic". (Webinar: Legal Society Forum: 13 June 2020);

[2] Soekanto, Soerjono. Introduction to Legal Research. Jakarta. UI-Press. 1986;

[3] Subekti. Principles of Civil Law. cet.32. Jakarta. Intermasa. 2003

[4] Blacks Law Dictionary. https://thelawdictionary.org/force-majeure / Accessed 20 Aug. 2020;

[5] Merriam-Webster.com Dictionary. MerriamWebster, 
webster.com/dictionary/force\%20majeure.

Accessed 20 Aug. 2020;

[6] Muhammad, Abdulkadir. Obligation Law. Bandung. Citra Aditya Bakti. 1992;

[7] Subekti. Contract Law. Jakarta. Intermasa. 1987;

[8] Isnaeni, Moch. Moch. Isnaeni. Lecture of Obligation Law at the Faculty of Law. Airlangga University. Surabaya. 21 September 2016;

[9] Purwanto Harry. Existence Principle of Rebus Sic Stantibus in International Agreements. Journal of Mimbar Hukum Special Edition, November 2011;

[10] Soemadipradja, Rahmat S.S. Explanation of Law on Force Majeure, National Legal Reform Program-Gramedia. Jakarta, 2010,;

[11] Asser. Study of Dutch Civil Law. Jakarta: Dian Rakyat. 1991; 